\title{
Usefulness of jejunal biopsy in the study of intestinal malabsorption in the elderly
}

\author{
B. Lobo, F. Casellas, I. de Torres ${ }^{1}$, L. Chicharro and J. R. Malagelada \\ Service of Digestive Diseases and 'Pathology. Hospital Universitari Vall d'Hebron. Barcelona, Spain
}

\begin{abstract}
Background: small bowel structure and function are not different between elderly people and young people. Thus, in principle it is advisable to perform diagnostic investigation of elderly patients as well as younger patients when they present with symptoms suggestive of intestinal malabsorption. A key test for the etiologic diagnosis of intestinal malabsorption, jejunal biopsy, has not been specifically examined to assess its usefulness and risk of complications in this advanced age patients.
\end{abstract}

Aim: to establish the usefulness of jejunal biopsy with the Watson's capsule in the elderly patients with suspected intestinal malabsorption.

Patients: patients older than 65 years referred to our Unit for performance of a jejunal biopsy from 1996 to 2001 for suspicion of intestinal malabsorption.

Results: forty-seven patients were included. Appropriate biopsy sample was obtained in 45 cases, although in 3 patients a second try was required. Histologic findings: partial villous atrophy in 10 cases $(22.2 \%)$, complete villous atrophy in 5 cases $(11.1 \%)$, intraepithelial lymphocytosis in 5 cases (11.1\%), and single cases of intestinal lymphangiectasia, amyloidosis, unspecific jejunitis, and Whipple's disease. Histology was normal in 19 cases (42\%). Definitive diagnosis was celiac disease in 14 patients, bacterial overgrowth in 3, jejunitis in 3, Whipple's disease in 1, lymphangiectasia in 1 , atrophic gastritis in 3 , amyloidosis in 1 , and ischemic colitis in 1 . Jejunal biopsy achieved an etiologic diagnosis in 20 patients. There were no cases of perforations or bleeding.

Conclusion: jejunal biopsy is a useful and safe test for the etiologic diagnosis of intestinal malabsorption in elderly patients.

Key words: Intestinal malabsorption. Elderly. Jejunal biopsy. Hydrogen breath test. Xylose test. Intestinal biopsy. Biopsy complications.

Lobo B, Casellas F, de Torres I, Chicharro L, Malagelada JR. Usefulness of jejunal biopsy in the study of intestinal malabsorption in the elderly. Rev Esp Enferm Dig 2003; 96: 259-264.

Recibido: 31-03-03.

Aceptado: 02-10-03.

Correspondencia: Francesc Casellas. Servicio de Aparato Digestivo. Hospital Universitari Vall d'Hebron. Barcelona. Pso. de la Vall'd Hebron, 119. 08035 Barcelona. Tel/fax: 934894456.

\section{INTRODUCTION}

Various studies have revealed that the structure, architecture and function of the intestinal mucosa in the elderly do not differ from those in the child or younger adult $(1,2)$. Moreover, D-xylose absorption does not begin to decrease until patients have more than 80 years of age (3). Thus, clinical or laboratory suspicion of malabsorption in the elderly should not be attributed to aging but instead must be adequately studied, since it may point out the presence of a small bowel disease. The causes of intestinal malabsorption in the elderly also resemble those in younger adults $(4,5)$. Most common causes include celiac disease, bacterial overgrowth, hypochlorhydria, Crohn's disease, mesenteric ischemia, and Whipple's disease (6-8).

Reported experience on the usefulness of screening tests is scarce regarding the study of intestinal malabsorption in the elderly. A hydrogen breath test with D-xylose is successfully used in both children and adults (9). This test is based upon the fact that orally administered xylose is absorbed through passive difusion in the small bowel; however, when the intestinal mucosa integrity is disrupted, xylose is not absorbed and thus reaches the colon, where it undergoes hydrogen-releasing fermentation. Hydrogen is absorbed and then eliminated in the breath, where it can be measured. This test has a good sensitivity and specificity for the screening of patients with malabsorption syndrome caused by small bowel disease (9-11). In older age patients, $\mathrm{H}_{2}$ breath test with $\mathrm{D}$-xylose has also proved to be useful with a sensitivity and specificity similar to those seen in adult patients (12).

The histological examination of biopsy samples from small bowel mucosa is a key factor in the etiologic diagnosis of intestinal malabsorption. Intestinal biopsy samples may be collected by using duodenal endoscopy or a jejunal biopsy capsule. The benefits of capsule biopsy versus endoscopic biopsy include sample size in view of histological examination, jejunal instead of duodenal sampling, and 
lower cost. However, shortcomings include radiation exposure and relatively prolonged examination time (13). Watson's capsule is a variant of Crosby's, which is used for jejunal biopsy collection since 1957 (14). Although much experience exists regarding jejunal biopsy in children, little is known about the usefulness and risk of jejunal biopsy in the etiologic evaluation of intestinal malabsorption in the elderly (15). As a result, our goal was to analyze the costeffectiveness of jejunal biopsy using Watson's capsule in the diagnosis of intestinal malabsorption in an advancedage population.

\section{MATERIAL AND METHODS}

\section{Patients}

Patients older than 65 years who had been referred to our Gastrointestinal Function Testing Unit from 1996 to 2001 to undergo jejunal biopsy under clinical suspicion of intestinal malabsorption were prospectively studied. The suspicion of malabsorption was based on both clinical parameters (chronic diarrhea, asthenia, weight loss, etc.) and laboratory data (ferropenic anemia, folic acid deficiency, vitamin $\mathrm{B}_{12}$ deficiency, hypocalcemia, hypocholesterolemia, hypoalbuminemia, positive celiac serology). All patients signed their informed consent to undergo jejunal biopsy.

\section{Methods}

Clinical data were collected for all patients, and all underwent hydrogen breath test with D-xylose before performing jejunal biopsy using the Watson's capsule.

For their hydrogen breath tests with D-xylose, patients were fasting and had received no antibiotics during the previous two weeks. Twenty-five grams of D-xylose in $250 \mathrm{~mL}$ of water were orally administered; exhaled breath samples were collected before and after D-xylose administration, and then every 30 minutes for 5 hours. Hydrogen concentration was measured as parts per million (ppm) using gas chromatography (Quintron), and results were then expressed as peak increases on $\mathrm{H}_{2}$ baseline production. Results were considered pathologic, i.e. suggestive of intestinal malabsorption, for increases above $25 \mathrm{ppm}$.

Patients were fasting at the time of jejunal biopsy. A biopsy capsule is ingested, and its progression to $10 \mathrm{~cm}$ past Treitz's angle is helped by postural changes under fluoroscopic control, so that jejunal mucosa samples may be collected. The mean duration time for biopsy is around 30 minutes; no anesthesia is needed and radiation exposure is minimal. Biopsy samples were routinely processed using formalin fixation and hematoxilin-eosin staining. Sample validity, jejunal mucosa morphology and architecture (villi, crypts, lamina propria cells, blood and lymphatic vessels), and technique-related complications were all evaluated.

\section{RESULTS}

\section{Patients}

Forty-seven patients ( 24 females and 23 males) with a mean age of 72 years (range: 66 to 84 years) were included in this study. Prior to biopsy, the mean duration of symptoms consistent with malabsorption syndrome was 17 months, with a confidence interval of 11.8 months. The most common presenting symptoms included chronic diarrhea in 27 patients (58\%), anemia in 19 patients (40\%), weight loss in 7 patients (15\%) and abdominal distension in one case $(2 \%)$.

Notable laboratory data included anemia in 19/44 (43\%), vitamin $\mathrm{B}_{12}$ deficiency in 10/29 (34\%), hypoalbuminemia in $11 / 39$ (28\%), hypocholesterolemia in 11/44 (25\%), hypocalcemia in 9/37 (24\%), and folic acid deficiency in 1/26 $(4 \%)$. Celiac disease serology (antiendomysium and antigliadin antibodies) was positive in 3 of 17 patients (18\%).

Hydrogen breath test with D-xylose was performed in 42 patients. Mean baseline $\mathrm{H}_{2}$ excretion was 16 ppm with a confidence interval of 8.2 , and average increase from baseline was $69 \mathrm{ppm}$ with a confidence interval of $34.0 \mathrm{ppm}$. The test yielded abnormal results in 39 (93\%) patients.

\section{Intestinal biopsy result}

A sample valid for histology was obtained in 42 patients $(89 \%)$. In a second attempt, a valid sample was collected in 3 of the previously failed 5 patients $(96 \%)$. Failed sample collection resulted from dysphagia, difficulty to pass through the pylorus, mouth aphthae difficulting catheter passage because of tenderness, and stomach sampling. No perforations or bleeding occurred.

Histological changes were seen in 55\% of intestinal mucosa biopsy samples. Partial atrophy was the most commonly found alteration (22\%). Other findings included total atrophy and lymphocytic infiltration, each in $11 \%$ of samples, as well as jejunitis in $7 \%$ of patients and isolated cases of amyloidosis, Whipple's disease or intestinal lymphangiectasia.

A probable etiologic diagnosis of malabsorption was obtained for $57 \%$ of patients. In more than one half of cases the diagnosis was based on intestinal biopsy findings. The most commonly found condition was celiac disease, which amounted for $52 \%$ of cases, followed by bacterial overgrowth $(15 \%)$, atrophic gastritis $(11 \%)$, jejunitis $(11 \%)$, and amyloidosis, Whipple's disease, intestinal ischemia, and intestinal lymphangiectasia making up the remaining $15 \%$. In 10 patients diagnosed histologically of celiac disease, the presence of antigliadin and antiendomysium antibodies had been previously investigated, but these were positive in just only 3 patients. However, such results are scarcely assessable since these tests had been performed, in some cases, following the introduction of a gluten-free diet. 
No histologic pattern is pathognomonic for celiac disease, which is characterized by various nonspecific findings (partial or total villous atrophy, lymphocyte infiltrates, etc.). Therefore, the criterion to confirm the diagnosis of celiac disease was a good -particularly clinical- response (weight gain and decreased diarrhea) to a gluten-free diet, with improved laboratory and/or histologic parameters.

\section{DISCUSSION}

To establish the usefulness and risks of the capsule intestinal biopsy in the elderly, we analyzed the results obtained in a group of 47 patients older than 65 years, who had been referred for a study of intestinal malabsorption syndrome suspected from clinical and laboratory data, and confirmed using hydrogen breath test with D-xylose. The usefulness of such intestinal malabsorption screening test was recently assessed in an older-age group of patients (12). This test has the advantage of not being influenced by age or renal function. Results obtained in this study reveal that jejunal histology is pathological in more than one half of patients of older age with suspected malabsorption, and that biopsy demonstrates the more likely etiology of intestinal malabsorption in $74 \%$ of cases. These results are in contrast with those reported, in 1978, by Linaker and Calam (15), who showed that the efficacy of jejunal biopsy was only $12 \%$ in the elderly. This discrepancy may be probably ascribed to differences in the selection of patients for biopsy, as a result of the long time lapse separating both studies.

In patients who had no histologic changes in jejunal biopsy samples, we attributed malabsorption to bacterial overgrowth (one case confirmed using the hydrogen breath test with glucose) (17), ischemic ileitis (one case demonstrated by colonoscopy and confirmed by histology), atrophic gastritis ( 3 cases revealed by histology), collagenous colitis (one case confirmed by colonoscopic biopsy), diarrhea secondary to drugs (one case in which diarrhea regressed following flutamide withdrawal and recurred following flutamide reintroduction), and infectious diarrhea in one patient in whom coproculture was positive for Blastocystis hominis; in the remaining patients, diarrhea was considered a chronic, nonspecific syndrome with a good response to loperamide.

As regards intestinal malabsorption causes, celiac disease is seen as the most common origin of malabsorption in this age group. The diagnosis of celiac disease was established on the presence of jejunal histologic lesions consistent with this diagnosis, together with good response to a gluten-free diet. The finding of an isolated positive serology was not considered diagnostic of celiac disease (18). This diagnosis is usually long delayed in the elderly, up to 28 years on average according to a published study (19). In this population subgroup, such diagnostic delay occurs even in the presence of a classical celiac disease manifestations (20). In other instances, however, this delay may be attributed to an atypical presentation -occa- sionally silent- or to a monosymptomatic presentation, such as anemia, iron deficiency, folic acid deficiency or hypocalcemia. However, early diagnosis is vital for these patients, since the incidence of serious complications, including intestinal lymphoma, may be prevented by the timely onset of an adequate dietary therapy (21). This is why screening tests such as the hydrogen breath test with D-xylose, and confirmation tests such as jejunal biopsy are so much advisable for elderly patients with clinically suspected malabsorption, since they are useful in the diagnosis of disease and have a low risk of iatrogenic complications.

To conclude, the results of the present study suggest that jejunal biopsy using Watson's capsule in the elderly is a useful, safe diagnostic procedure when it comes to establishing the causes of intestinal malabsorption.

\section{REFERENCES}

1. Corazza GR, Frazzoni M, Gatto MRA, et al. Ageing and small bowel mucosa: A morphometric study. Gerontology 1986; 32: 60-5.

2. Lipski PS, Bennett MK, Kelly PJ, James OF. Ageing and small-bowell morphometry. Journal of Clinical Pathology 1992; 45: 450-2.

3. Webster SGP, Leeming JT. Assessment of small bowel function in the elderly using a modified xylose tolerance test. Gut 1975; 16: 109.

4. Peter R, Holt MD. Diarrhea and malabsorption in the elderly. Gastroenterology Clinics of North America 2001; 30: 427-44.

5. Hoffmann JC, Zeitz M. Best Practice and Research Clinical Gastroenterology 2002; 16: 17-36.

6. Montgomery RD, Haboubi NY, Mike NH, et al. Causes of malabsorption in the elderly. Age Ageing 1986; 15: 235-40.

7. Montgomery RD, Haeney MR, Ross IN, et al. The ageing gut: A study of intestinal absorption in relation to nutrition in the elderly. Q J Med 1978; 47: 197-211.

8. Price HL, Gazzard BG, Dawson AM. Steatorrhoea in the elderly. BMJ 1977; 1: 1582.

9. Casellas F, Chicharro L, Malagelada JR. Potential usefulness of hydrogen breath test with D-xylose in clinical management of intestinal malabsorption. Dig Dis Sci 1993; 38: 321-7.

10. Carlson S, Craig RM. D- Xylose hydrogen breath tests compared to absorption kinetics in human patients with and without malabsorption. Dig Dis Sci 1995; 40: 2259-67.

11. Craig RM, Atkinson AJ. D-xylose testing: a review. Gastroenterology 1988; 95: 223-31.

12. Casellas F, Sardi J, de Torres I, Malagelada JR. Hydrogen breath test with D-xylose for celiac disease screening is as useful in the elderly as in other age groups. Dig Dis Sci 2001; 46: 2201-5.

13. Mee AS, Burke M, Vallon AG, Newman J, Cotton PB. Small bowel biopsy for malabsorption: comparison of the diagnostic adequacy of endoscopic forceps and capsule biopsy specimens. Br Med J 1985; 291: 769.

14. Linaker BD, Calam J. Jejunal biopsy with the Watson capsule and perforation in the elderly. Gastroenterology 1978; 75: 723-5.

15. Linaker BD, Calam J. Is jejunal biopsy valuable in the elderly? Age Ageing 1978; 7: 244

16. Casellas F, de Torres I, Malagelada JR. Follow-up of celiac disease with the D-xylose breath test. Dig Dis Sci 1996; 41: 2106-11.

17. Casellas F, Guarner L, Vaquero E, Antolín M, de Gracia X, Malagelada JR Hydrogen breath test with glucose in exocrine pancreatic insufficiency. Pancreas 1998; 16: 481-6.

18. Clinical Practice and Practice Economics Committee. American Gastroenterological Association Medical Position Statement: Celiac Sprue. Gastroenterology 2001; 120: 1522-5.

19. Hankey GL, Holmes GKT. Coeliac disease in the elderly. Gut 1994; 35 $65-7$

20. Gasbarrini G, Ciccocioppo R, de Vitis I, Corazza GR. Coeliac disease in the elderly. Gerontology 2001; 47: 306-10.

21. Tai V, Crowe M, O'Keeffe S. Celiac disease in older people. J Am Geriatrics Soc 2000; 48: 1690-6. 


\title{
Utilidad de la biopsia yeyunal en el estudio de la malabsorción intestinal en el anciano
}

\author{
B. Lobo, F. Casellas, I. de Torres ${ }^{1}$, L. Chicharro y J. R. Malagelada \\ Servicios de Aparato Digestivo y 'Anatomía Patológica. Hospital Universitari Vall d'Hebron. Barcelona
}

\section{RESUMEN}

Fundamento: la estructura y función del intestino delgado en el anciano sano y en el joven no difieren. Por este motivo ante la sospecha clínica de malabsorción intestinal en el anciano siempre deben realizarse las pruebas necesarias para identificar su causa. Una prueba clave en el estudio de la malabsorción intestinal es la biopsia yeyunal, cuya utilidad, eficacia o complicaciones, son poco conocidas en el grupo de población de edad avanzada.

Objetivo: determinar la utilidad de la biopsia yeyunal con la cápsula de Watson en el anciano.

Pacientes: pacientes de edad superior a los 65 años, remitidos para biopsia yeyunal desde 1996 a 2001 por sospecha de malabsorción intestinal.

Resultados: se han incluido 47 pacientes. La biopsia obtuvo muestra útil para estudio histológico en 42 casos, obteniendo muestra en un segundo intento en 3 de los 5 fracasos iniciales. La histología demostró atrofia vellositaria parcial en 10 casos $(22,2 \%)$, atrofia vellositaria completa en $5(11,1 \%)$, linfocitosis intraepitelial en $5(11,1 \%)$, y casos aislados de linfangiectasia intestinal, amiloidosis, yeyunitis inespecífica y enfermedad de Whipple. La histología fue normal en 19 casos (42\%). El diagnóstico definitivo fue enfermedad celíaca en 14 pacientes, sobrecrecimiento bacteriano en 3, yeyunitis en 3 , enfermedad de Whipple en 1 , linfangiectasia en 1 , gastritis atrófica en 3 , amiloidosis en 1 (asociada a sobrecrecimiento bacteriano), y colitis isquémica en 1. La biopsia yeyunal fue esencial para el diagnóstico en 20 pacientes. No se registró perforación o hemorragia en ningún paciente.

Conclusión: en el estudio de la malabsorción intestinal del anciano, la biopsia yeyunal es un método diagnóstico útil y seguro para identificar la causa de la malabsorción.

Palabras clave: Malabsorción intestinal. Anciano. Biopsia yeyunal. Test del aliento de hidrógeno. Test de xilosa. Biopsia intestinal. Complicaciones biopsia.

\section{INTRODUCCIÓN}

Diversos estudios han demostrado que la estructura, arquitectura y función de la mucosa intestinal en el anciano no difiere de la del niño o del adulto joven $(1,2)$. Incluso la absorción de D-xilosa no comienza a disminuir hasta después de los 80 años (3) de edad. Por lo tanto, la sospecha clínica o analítica de malabsorción en el anciano no debe atribuirse a la edad sino que debe ser estudia- da de la forma adecuada, dado que puede indicar la existencia de patología del intestino delgado. La causa de la malabsorción intestinal en el anciano es también similar a la del joven $(4,5)$. Entre las más comunes deben considerarse la enfermedad celíaca, sobrecrecimiento bacteriano, hipoclorhidria, enfermedad de Crohn, isquemia mesentérica y la enfermedad de Whipple (6-8).

Existe poca experiencia publicada acerca de la utilidad de las pruebas de cribaje para el estudio de la malabsorción intestinal en el anciano. En el niño y el adulto se utiliza con éxito la prueba del aliento de hidrógeno con D-xilosa (9). Esta prueba se basa en el hecho de que la xilosa administrada por vía oral y absorbida por difusión pasiva en el intestino delgado, ante una alteración de la integridad de la mucosa intestinal, no es absorbida y así alcanzará el colon donde será fermentada liberando hidrógeno. Este se absorbe y se elimina por el aliento, donde puede ser medido. Esta prueba tiene una buena sensibilidad y especificidad para discriminar pacientes con malabsorción debida a patología de la mucosa intestinal (9-11). En los pacientes de edad avanzada, la prueba del aliento de $\mathrm{H}_{2}$ con D-xilosa también ha demostrado su utilidad, con una sensibilidad y especificidad similares a las que se obtienen en el adulto (12).

El estudio histológico de biopsias de la mucosa del intestino delgado es clave para el diagnóstico etiológico de la malabsorción intestinal. La obtención de biopsias intestinales puede conseguirse mediante endoscopia duodenal o con cápsulas de biopsia yeyunal. Las ventajas de las biopsias realizadas con cápsula frente a las realizadas con endoscopia son el tamaño de la muestra para examen histológico, la obtención de biopsias yeyunales en vez de duodenales y el bajo coste de la técnica. Sin embargo, tiene también inconvenientes como son la exposición a radiación y el tiempo relativamente prolongado que requiere la exploración (13). La cápsula de Watson es una variante de la cápsula de Crosby que se utiliza para obtener biopsias yeyunales desde 1957 (14). Aunque en el niño existe mucha experiencia en la obtención de biopsias yeyunales, conocemos muy poco sobre la utilidad y 
el riesgo de la biopsia yeyunal en el estudio de la causa de la malabsorción intestinal en el anciano (15). Por ello, nuestro objetivo ha sido analizar la rentabilidad de la biopsia yeyunal obtenida mediante cápsula de Watson en el diagnóstico de la malabsorción intestinal en la población de edad avanzada.

\section{MATERIAL Y MÉTODOS}

\section{Pacientes}

Se han estudiado de forma prospectiva aquellos pacientes con una edad mayor de 65 años que fueron remitidos a la Unidad de Pruebas Funcionales Digestivas desde el año 1996 hasta el 2001 para la práctica de biopsia yeyunal por sospecha clínica de malabsorción intestinal. La sospecha de malabsorción se fundamentó en parámetros clínicos (diarrea crónica, astenia, pérdida de peso, etc.) y analíticos (anemia ferropénica, déficit de ácido fólico, déficit de vitamina $\mathrm{B}_{12}$, hipocalcemia, hipocolesterolemia, hipoalbuminemia, serología celíaca positiva). Todos los pacientes firmaron un consentimiento informado aceptando la realización de la biopsia yeyunal.

\section{Método}

En todos los pacientes se recogieron los datos clínicos, se practicó una prueba del aliento de hidrógeno con D-xilosa y posteriormente la biopsia yeyunal con cápsula de Watson.

Para realizar la prueba del aliento de $\mathrm{H}_{2}$ con D-xilosa (16) los pacientes acudieron en ayunas y sin haber recibido tratamiento antibiótico alguno en las dos semanas previas. Se administraron por boca 25 gramos de D-xilosa en $250 \mathrm{ml}$ de agua, obteniéndose muestras del aliento exhalado antes de administrar la D-xilosa y posteriormente cada 30 minutos durante 5 horas. Se determinó la concentración de hidrógeno en partes por millón mediante cromatografía de gases (Quintron) y se expresó el resultado como incremento máximo sobre la producción basal de $\mathrm{H}_{2}$. El resultado se consideró patológico, sugestivo de malabsorción intestinal, cuando el incremento fue mayor de 25 ppm.

Para la realización de la biopsia yeyunal los pacientes acudieron en ayunas. La cápsula de biopsia se deglute y, mediante cambios posturales, se consigue su progresión hasta superados al menos $10 \mathrm{~cm}$ distales al ángulo de Treitz, lo que se confirmó mediante control fluoroscópico, para conseguir muestras de mucosa yeyunal. El tiempo medio de dicha técnica es aproximadamente de unos 30 minutos, realizándose sin precisar anestesia y con mínima irradiación. Las muestras obtenidas en la cápsula se procesaron según técnica de rutina mediante fijación con formol y tinción con hematoxilina-eosina. Se valoraron la obtención de muestra útil, la morfología y arquitectura de la mucosa yeyunal (vellosidades, criptas, celularidad de la lámina propia, vasos sanguíneos y linfáticos) y las complicaciones de la técnica.

\section{RESULTADOS}

\section{Pacientes}

En total se incluyeron en el estudio 47 pacientes ( 24 mujeres y 23 varones) con una edad media de 72 años y un rango de 66 a 84 años. El tiempo medio de evolución de los síntomas consistentes con posible malabsorción, previa a la realización de la biopsia, fue de 17 meses, con un intervalo de confianza de 11,8 meses. Los síntomas de presentación más frecuentes fueron diarrea crónica en 27 casos $(58 \%)$ y anemia en 19 (40\%), seguidas de pérdida de peso en 7 (15\%) y distensión abdominal en un caso aislado $(2 \%)$.

Los datos analíticos más destacados fueron anemia en 19/44 (43\%), déficit de vitamina $B_{12}$ en 10/29 (34\%), hipoalbuminemia en 11/39 (28\%), hipocolesterolemia en 11/44 (25\%), hipocalcemia en 9/37 (24\%) y déficit de ácido fólico en 1/26 (4\%). La serología para celiaquía (anticuerpos antiendomisio y antigliadina) fue positiva en 3 de los 17 pacientes en los que se practicó (18\%).

La prueba del aliento de $\mathrm{H}_{2}$ con D-xilosa se realizó en 42 de los pacientes incluidos. La excreción media de $\mathrm{H}_{2}$ basal fue de 16 ppm con un intervalo de confianza de 8,2 y el promedio del incremento sobre la basal de 69 ppm con un intervalo de confiaza de $34,0 \mathrm{ppm}$. La prueba fue anormal en $39(93 \%)$ de los pacientes.

\section{Resultado de la biopsia intestinal}

Se obtuvo muestra útil para el estudio histológico en 42 casos (89\%). En un segundo intento se consiguió muestra útil en 3 de los 5 pacientes (96\%). El fallo en la obtención de muestra se debió a disfagia, dificultad para franquear el píloro, aftas bucales que dificultaron la introducción de la sonda por dolor y muestra procedente del estómago. No se registró perforación o hemorragia en ningún paciente.

Se observaron alteraciones histológicas en el $55 \%$ de las muestras de la biopsia mucosa intestinal obtenida. La alteración más frecuente fue la atrofia parcial (22\%). Otros hallazgos fueron la atrofia total y la linfocitosis, cada una de ellas en el $11 \%$ de las muestras, yeyunitis en el $7 \%$ y casos aislados de amiloidosis, enfermedad de Whipple y linfangiectasia intestinal.

El diagnóstico etiológico probable de la malabsorción intestinal se obtuvo en el $57 \%$ de los pacientes. En más de la mitad de los casos el diagnóstico se realizó por los hallazgos de la biopsia intestinal realizada con cápsula. La patología más frecuente fue la enfermedad celíaca, que representó el 52\%, seguida del sobrecrecimiento bac- 
teriano $(15 \%)$, gastritis atrófica $(11 \%)$, yeyunitis $(11 \%)$, amiloidosis, enfermedad de Whipple, isquemia intestinal y la linfangiectasia intestinal que configuran el $15 \%$ restante. En 10 pacientes diagnosticados de enfermedad celíaca mediante biopsia intestinal se había determinado previamente la existencia de anticuerpos antigliadina o antiendomisio, que fueron positivos solamente en 3 casos, dichos resultados son poco valorables dado que en algunos casos se realizó posteriormente a la introducción de la dieta sin gluten.

No hay un patrón histológico patognomónico de la enfermedad celíaca, sino una serie de hallazgos no específicos (atrofia vellositaria parcial o total, infiltración linfocitaria,...). Por ello, el criterio de confirmación utilizado para el diagnóstico de enfermedad celíaca fue una buena respuesta principalmente clínica (aumento de peso y disminución de la realización de diarrea), mejoría de parámetros analíticos y/o histológicos a la dieta sin gluten.

\section{DISCUSIÓN}

Con el objeto de determinar la utilidad y los riesgos de la biopsia intestinal con cápsula en el anciano se han analizado los resultados obtenidos en un grupo de 47 pacientes con una edad superior a 65 años, que habían sido remitidos para estudio de una posible malabsorción intestinal sospechada por datos clínicos-analíticos y confirmada en la mayoría de pacientes mediante el test del aliento de hidrógeno con D-xilosa. La utilidad de esta prueba de cribaje para la malabsorción intestinal ha sido valorada recientemente en el grupo de edad avanzada (12), y tiene las ventajas de no estar influida por la edad, ni la función renal. Los resultados obtenidos en el presente estudio demuestran que la histología yeyunal es patológica en más de la mitad de los pacientes de edad avanzada con sospecha de malabsorción, y que la biopsia descubre la etiología probable de la malabsorción intestinal en el 74\% de los casos. Estos buenos resultados contrastan con los publicados en 1978 por Linaker y Calam (15), que describen una eficacia de la biopsia yeyunal en el anciano de solamente el $12 \%$. Esta discrepancia probablemente puede explicarse por diferencias en la selección de los pacientes tributarios de la biopsia, debido al largo intervalo de tiempo que separa ambos estudios.
Atribuimos la malabsorción en los pacientes que no presentaban alteraciones histológicas en la biopsia yeyunal a sobrecrecimiento bacteriano (1 caso, confirmado por test del aliento de hidrógeno con glucosa) (17), ileítis isquémica (1 caso, evidenciada por colonoscopia y confirmada por histología) gastritis atrófica (3 casos, evidenciadas por histología), colitis colágena (1 caso, confirmada por histología realizada en muestra obtenida tras colonoscopia), diarrea secundaria a fármacos (1 caso, remitida la clínica de diarrea tras la retirada de flutamida y reproducción de la misma tras su reintroducción), 1 caso de diarrea de etiología infecciosa tras hallazgo de coprocultivo positivo para Blastocystis hominis, en el resto de pacientes la diarrea se orientó como síndrome diarreico crónico inespecífico con buena respuesta a loperamida.

En cuanto a las causas de la malabsorción intestinal, se observa que la enfermedad celíaca en este grupo de edad es la causa más frecuente de malabsorción. El diagnóstico de enfermedad celíaca se estableció en base a la existencia de lesiones histológicas yeyunales compatibles con dicho diagnóstico junto a buena respuesta a la dieta sin gluten, y no al hallazgo aislado de una serología positiva (18). El diagnóstico de la enfermedad celíaca en el anciano suele realizarse con mucho retraso, que en un estudio publicado alcanza hasta los 28 años de promedio (19). Dicho retraso en el diagnóstico en este subgrupo de la población tiende a ocurrir incluso cuando la presentación clínica de enfermedad celíaca sea la clásica (20). En otros casos, sin embargo, puede atribuirse a la atipicidad de su presentación clínica, en algunos casos silente, o a su presentación monosintomática con anemia, déficit de hierro, ácido fólico o hipocalcemia. Sin embargo, el diagnóstico precoz es trascendente ya que la incidencia de complicaciones importantes, incluido el linfoma intestinal, podrían prevenirse instaurando el tratamiento dietético adecuado a tiempo (21). Por este motivo es tan aconsejable aplicar exploraciones de cribado, como la prueba del aliento de hidrógeno con D-xilosa, y de confirmación, como la biopsia yeyunal, en casos de sospecha clínica de malabsorción en el anciano dada su utilidad para el diagnóstico, y el bajo riesgo de complicaciones yatrogénicas que conlleva.

En conclusión, los resultados del presente estudio sugieren que la biopsia yeyunal con cápsula de Watson en el anciano es un método diagnóstico útil y seguro para identificar la causa de la malabsorción intestinal. 